\title{
THE DAY OF THE DEAD: ONE RITUAL, NEW FOLK COSTUMES, AND OLD IDENTITIES
}

\author{
Rosa Isela Aguilar Montes de Oca
}

\begin{abstract}
The article provides an analysis of the role of the folk costumes in the attempts to revitalize an authentic cultural identity within a geographical region and to oppose the effects of external cultural influence. The inhabitants of La Huasteca region in Hidalgo, Mexico, perceive Halloween - imported to Mexico through international migration and media in the decade of 1980 - as potential threat to the local tradition of the Day of the Dead. The costumes used for the Miss Cempoalxóchitl contest, a pageant performed on November 1 and initiated in Tehuetlán in 1989, display important items of the celebration to reinforce the Day of the Dead ritual, to rebuild La Huasteca region and the Huasteco identity, and to create a direct kinship with the Toltecs. This ritual, celebrated once a year to gather the living and their dead relatives, has economic, cultural, and social functions, which are fostered through the Miss Cempoalxóchitl beauty pageant.
\end{abstract}

Keywords: Day of the Dead, folk costume, heritage, indigenous identity, Mexico, ritual, symbolic object

\section{INTRODUCTION}

The traditional Mexican ritual, the Day of the Dead (Día de Muertos), was inscribed in the Representative List of the Intangible Cultural Heritage of Humanity by UNESCO in 2008. As an old tradition that combines Spanish and pre-Hispanic cultural elements and is transmitted through generations, this festivity is dynamic and transforms itself continuously in creative ways. Ortiz (1995 [1947]) asserted that culture is the result of a complex process of transmutations. He called this process transculturation to explain the continuous readjustment through cultural transplantations. The process follows a disadjustment and readjustment, deculturation and acculturation, that is, transculturation. In America, the transcultural processes were initiated in the 15th century with the arrival of Spanish culture, a representative of Mediterranean, African, and many other cultures. The redefinition of cultural borders through intercultural encounters takes place then in transcultural spaces, which connect different space-time venues even when distant geographically and chronologically (Schütze \& Zapata 2007). Global flows include a part that 
uniforms and another that reinforces the production of cultural difference (Meyer \& Geschiere 1999). Transnational intercultural encounters are important in the construction of gender, ethnicity, race, and nationality (Kummels 2007). Migration has been analyzed as one of the main experiences that impact the cultural analysis of locality against global processes (Dürr 2009). The media is an important transmitter, modifier, and re-producer of culture (Schlehe 2005) as well.

This article ${ }^{1}$ stresses the transcultural transformations of the Day of the Dead and the political, economic, and social functions of the new folk costumes for the Miss Cempoalxóchitl beauty pageant in Tehuetlán, in La Huasteca, Hidalgo, Mexico.

Brandes (1998) says that the Mexican Day of the Dead ritual is a political enterprise that promotes a national cultural identity. Cultural differentiation and national distinctiveness have been needed to keep distance from Spain and the United States; hence, they are promoted by the Mexican state. Originality and authenticity were important during the War of Independence that ended the rule of Spain in 1821, and again increased in importance beginning in the 1840 s, after the loss of half of its territory. ${ }^{2}$ Mexican intellectuals, journalists, government officials, and several institutions have promoted this international symbol of Mexico for decades. The Mexican Nobel Prize in Literature 1990, Octavio Paz, wrote:

The Mexican... is familiar with death, jokes about it, caresses it, sleeps with it, celebrates it; it is one of his toys and his most steadfast love... The Mexican indifference toward death is fostered by his indifference toward life... It is natural, even desirable to die, and the sooner the better. (Paz 1961: 57-58)

The state cultural institutions promote contests of original altars all around Mexico and discard those influenced by US American items, such as Halloween pumpkins, masks, and sweets. Halloween symbols coming into Mexico are experienced by the government as a cultural threat even when this Mexican national identity reinforces the image of the morbid, death-obsessed Mexicans (Brandes 2003: 141). The population in Mexico is very aware of this cultural threat and makes big efforts to represent an original ritual in their towns.

The Day of the Dead fosters local economy (Haley \& Fukuda 2004; Brandes 2003), and it brings international migrants home (Marchi 2005; Haley \& Fukuda 2004). The politics of the Day of the Dead have been analyzed in the American diaspora $^{3}$ (Marchi 2005; Orellana 2011a) and in the urban context (Orellana 2011a), but much less in rural contexts. The Day of the Dead in Tehuetlán 
serves to construct an old cultural identity, to reinforce economic development and kinship ties, and to introduce new gender representations.

I participated in the Xantolo ritual on the Day of the Dead in 2011, and witnessed the Miss Cempoalxóchitl contest together with the pueblo of Tehuetlán. During my visit, I observed a remarkable difference between this particular ritual and those performed in other places in the State of Hidalgo. I was surprised to see the huge emotion that the contest provoked in people and how they were enjoying it even if it was organized in a very US American style, which they wanted to avoid in the first place. Also, some people in town regarded it as improper to reinforce a tradition for the dead with a mundane contest. Nevertheless, they were so excited that they used professional cameras, as those used in TV productions, even though the event remained local. There were no tourists; I and a photographer from a newspaper from the capital of the state, Pachuca, who had followed my advice, were the only ones. This contest has no parallel in Mexico, as far as it is known.

\section{THE DAY OF THE DEAD IN MEXICO}

Halloween and the Day of the Dead share historical symbolic origins (Brandes 1998). Halloween is a part of Scottish and Irish folk customs of pre-Christian times. The pagan Druid priests believed that souls were immortal and they passed from one body to another at death. On the last night of the old year (October 31) the Lord of the Dead, Saman, gathered the condemned souls together to inform them which animal they should inhabit for the next year. This pagan celebration became Catholic, as November 1 is celebrated as All Saints' Day (Hallowmas), and October 31 as All Hallows' Eve (Halloween). The Catholic Church introduced All Souls' Day on November 2 to give gifts and pray for the souls to go to heaven. Odilo, Abbot of Cluny, France, introduced the ceremony of praying to or for the dead into church in the 11th century, and two centuries later it was widespread (Linton 1951).

The Christian days dedicated to the dead merged partially with the Mexica (better known as Aztec) celebrations of the dead during the colonial era (Orellana 2011b). The Mexica dedicated two main ceremonies to the dead.

1. Tlaxochimaco (the birth of flowers), or Miccailhuitontli, on the ninth month of the Mexica year, was a small festivity or a festivity for the dead children. The small dead went to the highest, divine heaven, where they would reintegrate to the cosmos. For this festivity people picked flowers in the fields, which represented children who were offered to the god called 
Huitzilopochtli. According to written records, this festivity was celebrated already in the 16 th century.

2. On the last day of the tenth month, men had to cut down a tree; when cleared, this tree (called Xócotl) was honored with offerings and food. The mast symbolized fertility, life, and the old men surrounding the mast on four sides represented the dead. Xócotl Uetzi, or Hueymiccaihuitl, honored the old dead. The dead were able to come to and leave the town twice a year, at the beginning of the year, on the spring equinox, and on the autumn equinox.

Other Mexica ceremonies served to honor different gods as well as dead bodies and souls according to the manner in which the person had died. ${ }^{4}$ The festivity to honor Mixcóatl, the hunting and astral god, and those who had died in the war and would go up to the sun and come down in the afternoon, transformed into butterflies and humming birds, was celebrated in the month of Quecholli (the fourteenth month in the Aztec calendar). In the 16th century, when it was first introduced by Spanish missionaries, this ceremony coincided with the Catholic festivity of All Saints. The new Mexican ritual of the dead honors dead children on November 1 , and dead adults on November 2, as in the Mesoamerican tradition. A yellow corn bread of wrinkly skin, cocolli, made out of the sacred seeds of some cobs, ocholli, was used for the celebration of Xipe Tótec, the autumn god, and used as an offering to resemble death (Dufétel 2011). That is maybe the origin of the recent offerings to the dead.

Today, the rituals for the dead are performed in very different ways in Mexico. There are thousands of different rituals of the Day of the Dead, but despite the huge diversity within regions, the constant is people building altars in homes all around the country. There are all sorts of ofrendas (offerings); they consist of objects with symbolic meanings, set on altars at home or on graves in the churchyard: Cempoalxóchitl flowers (the Mexican marigold) expanding their scent; water and salt representing life; candle lights, incense burners, and copal guide the dead into the world of the living, and the food (mainly tamales $^{5}$ ), drink, and music bring joy to the dead. Sugar skulls and photographs that depict the dead person replace the practice of Mesoamericans, who used to dig up the remains of their dead to clean up the bones and paint the skull in bright colors, forbidden after the Conquista (Spanish colonization) (Haley $\&$ Fukuda 2004). Distinguishing between urban-western and rural-indigenous celebration began in the 19th century, when indigenous rituals were seen as backwardness, as the main obstacle for national modernization. The urban festivity abounds in skeletons, Grim Reapers, and sugar skulls that are not found in small towns. Here, the most important symbol is the food that the dead enjoyed in life (Orellana 2011b). 


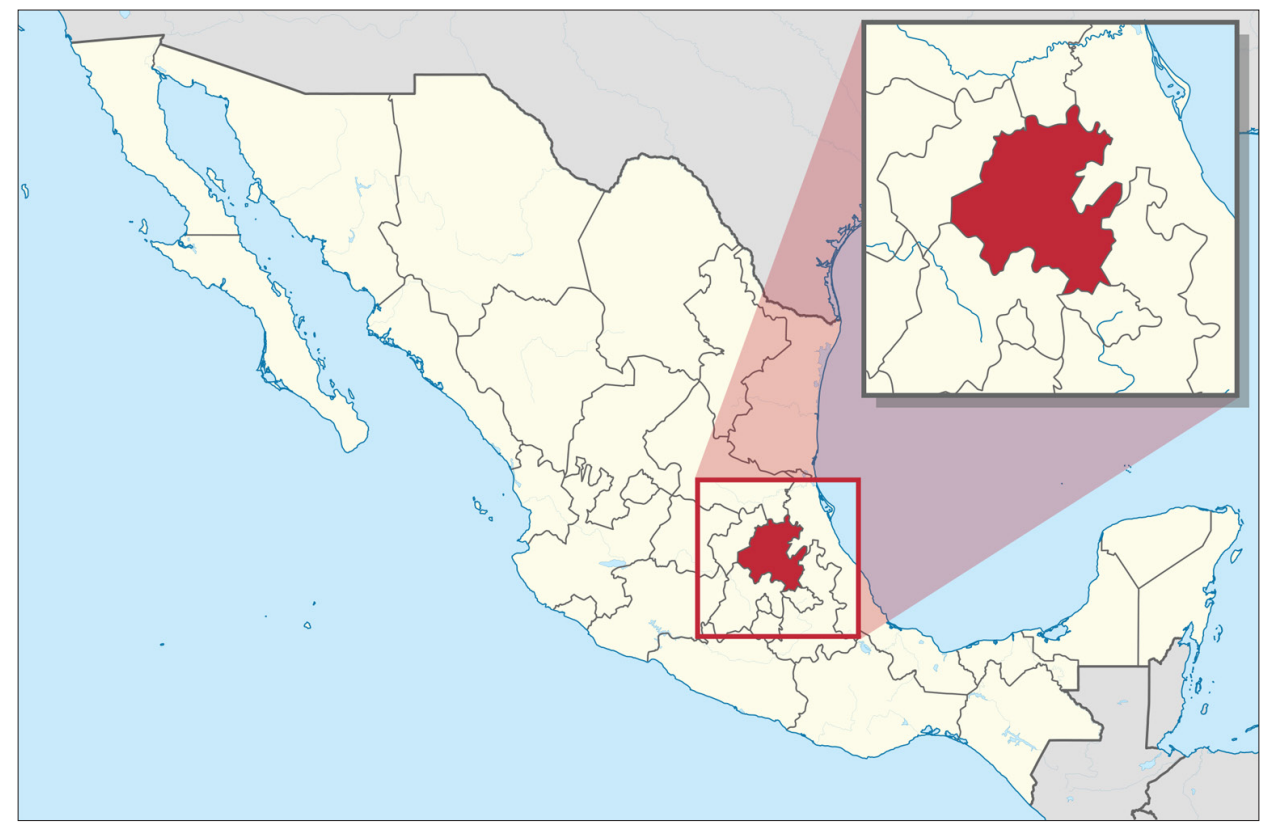

Figure 1. La Huasteca in Hidalgo, Mexico (https: / / commons.wikimedia.org / wiki/File:Hidalgo_in_Mexico_(zoom).svg).

Another difference is that Christians pray for the souls of the dead, whereas Mesoamericans, through the rituals performed in small towns, pray to the souls of dead relatives (Lechuga 2011).

\section{THE DAY OF THE DEAD IN LA HUASTECA: XANTOLO}

In La Huasteca, the Day of the Dead is slightly different from that in other regions of Mexico. La Huasteca, in the center of Mexico (Fig. 1), is a relatively confined region, mainly because of its difficult geographical access: it is surrounded by a green and fertile mountain chain, and there are frequent fractures on the roadway. The region experiences political difficulties and violence.

Spaniards introduced All Saints' and All Souls' days into La Huasteca through the Catholic missions, and the Huastecos called the celebration Xantolo, an adaptation in the Náhuatl ${ }^{6}$ language of the Latin word Sanctorum ('of 


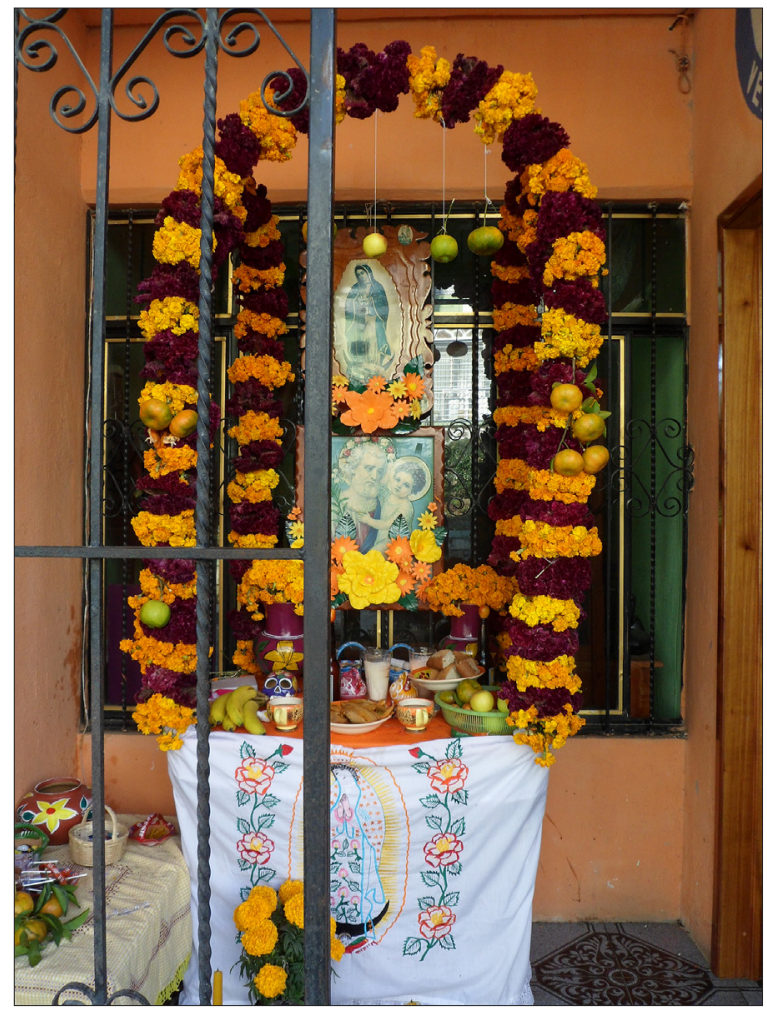

Figures 2, 3. Representative of the Xantolo is the arch of flowers, palms, and fruit. The dances have a strong US American influence. The Comanches are represented as those who scare the dead. Cowboys lead this activity and protect pregnant women in order to preserve life. Tehuetlán, Hidalgo, Mexico. Photographs by Rosa Isela Aguilar Montes de Oca 2011.

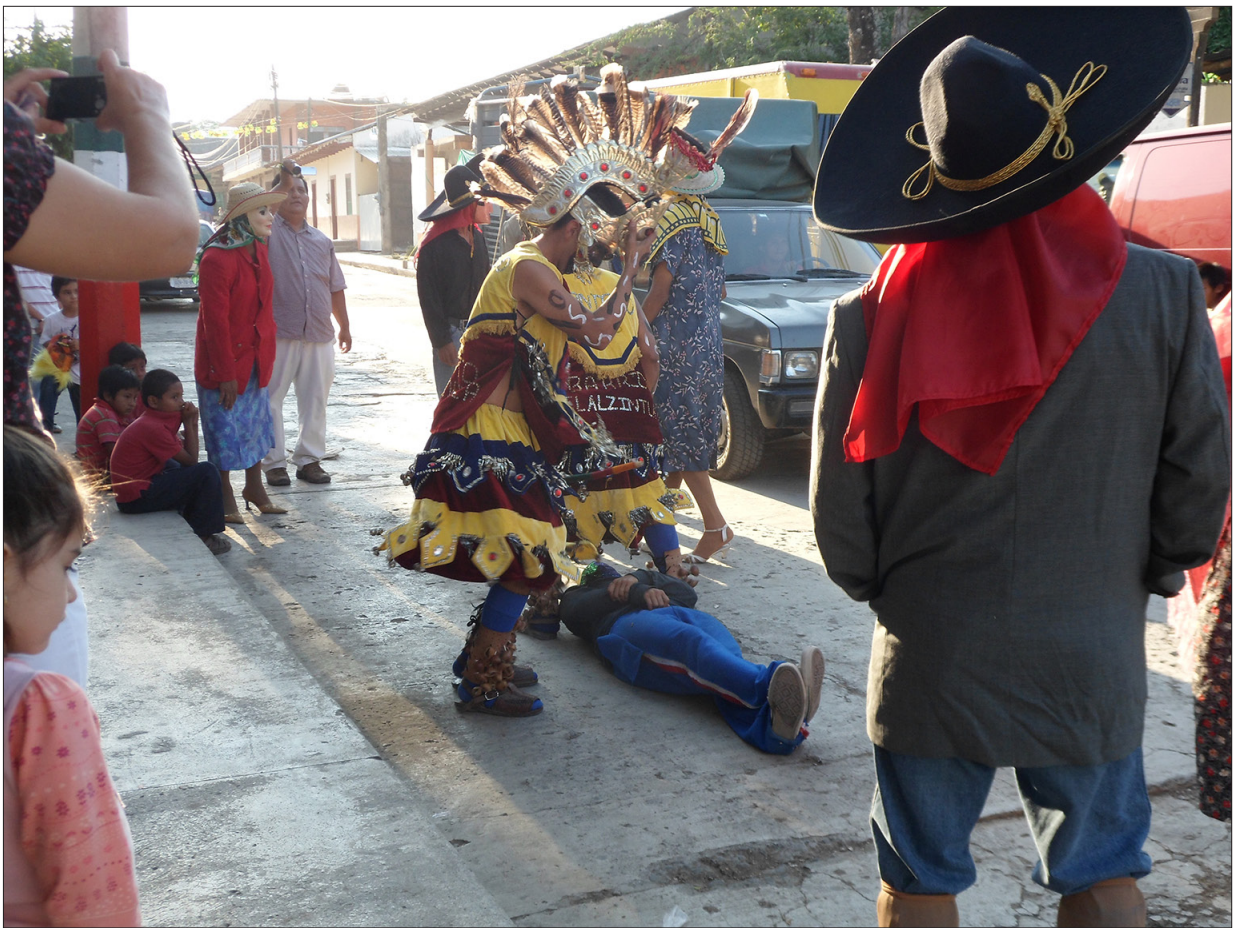


the Holies': de los Santos). In the small town of Tehuetlán, the Xantolo ritual is celebrated with altars and dances (Figs. 2,3).

The ritual starts on October 30, when the family works together, decorating the altar. The altar is divided into three different levels: the upper level represents heaven; the middle level - earth, and the lowest level - the underworld (Vargas del Ángel 2010). Characteristic of Xantolo altars are the arches of flowers that are made out of cane sticks and palms, and symbolize the gate leading from life to death. Small altars with small arches are prepared for deceased children. On October 31 the family surrounds the altar. There they place the offering of natural and cultural products and objects particularly symbolic of La Huasteca region: tamales, chocolate, oranges, peanuts, limes, sweet potatoes, guavas, bananas, lemons, clay candle holders with figures representing animals and flowers, especially cempoalxóchitl and mano de león (Celosia cristata - cockscomb) in clay pots. The family members living abroad arrive on this day too. Together, they light candles, honor the deceased person in the photograph, clean the space with the smoke of copal, and set a path of petals guiding the dead spirit from the entrance door to the altar. When the altars are ready, fireworks are lighted to tell the spirits of the dead that they can come home. Outside, the community enjoys the dances of people disguised as cowboys, Comanches ${ }^{7}$, pregnant women, and a personification of Death, which, as part of the cycle of life, represents leadership, defense, new life, and the end of life. Their task is to distract or trap Death to allow the dead members of the family to come home and enjoy the festivity. Music accompanies dances and fills the whole town. Guitars and violins are heard during the whole journey of the dead and also on the following days. This day is dedicated to those who died a violent death, in an accident, or suicide (Vargas del Ángel 2010).

On November 1 fireworks welcome the small dead children. For them, the offering consists of small breads and tamales, chocolate, fruit, and toys. At lunchtime soup, rice, vegetables, and soft meat are served, and later on a portion of dessert. The family sits around the table to talk about life, to remember the dead members of the family, and to eat tamales. On November 2 they honor the dead adults. Altars are covered with tamales stuffed with turkey, chicken, or pork prepared with chilies and other condiments, as well as bread, rice, beer, tequila, and maybe tobacco - everything that the person enjoyed in life. Some people place clothes, shoes, and tools as offerings (Vargas del Ángel 2010). On November 3 they set a small altar outside the house and place some tamales for those who have no family to visit, for the lonely spirits (ánima sola). During the five days of Xantolo, members of the community meet in the churchyard to clean and decorate the graves, but for some this is too sad and they remain at home. During these days they cook and eat tamales, the main object of the 
reciprocity system used these days to confirm kinship ties. They serve tamales to the family members and give them a package of tamales to take back home when they leave. In town one can see many people coming and going, carrying packages of tamales to exchange with the neighbors. They visit each other to exchange gifts, but visits are not restricted to one community; people come from different communities.

A family from a small town brought tamales to the family I was staying with, as well as venison stuffed with chilies and green beans - specialties of their hometown. The packaging is of the same importance as tamales. Since months prior to the festivity, natural fibers were woven by men to make the typical haversacks (morral) to transport the gifts. Women embroidered cloth napkins by hand. During the visit that lasted three or four hours, the host family served tamales, chocolate, and coffee.

The ritual gradually changed because the population of La Huasteca had started a massive migration process to the USA in the decade of 1960 due to demographic and economic pressure: the rapid population growth, the slump of the international coffee and sugar prices, crop losses, and an agrarian conflict (Schryer 1990). On their return, the migrants brought all kinds of US Ameri-

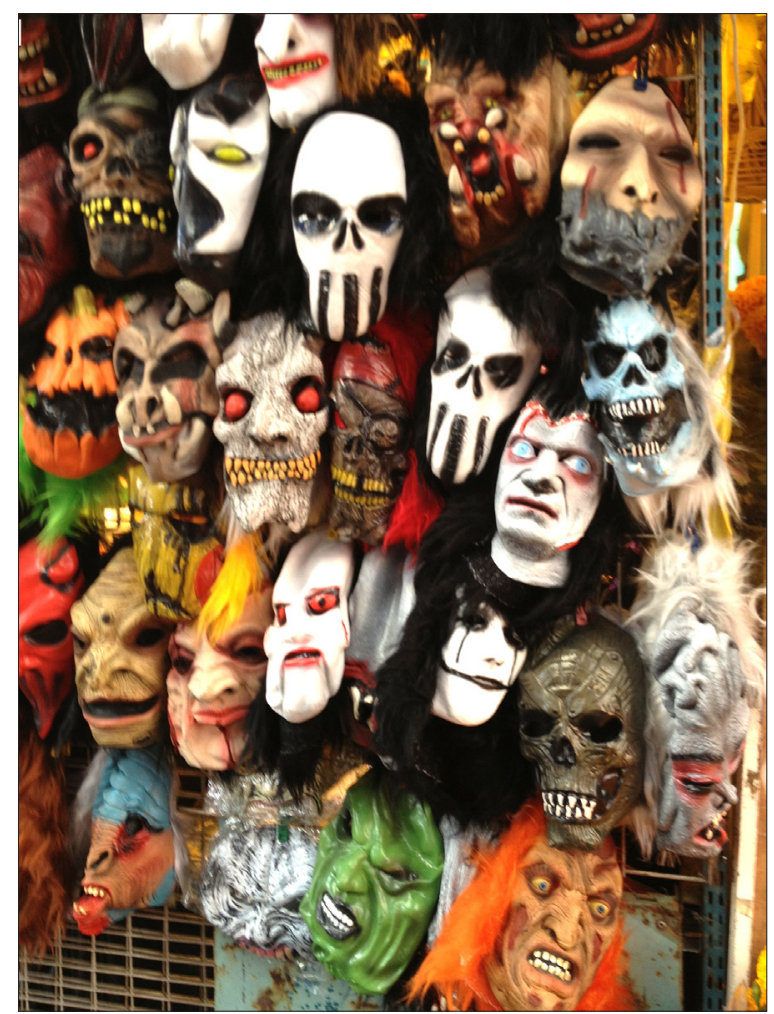

can influences (Halloween masks, remittances, TV-sets, home appliances, etc.) with them, by doing so accelerating the state's modernization
Figure 4. Plastic masks are sold in the markets around the Day of the Dead in Mexico. They attract people's attention and are less expensive than the wooden Mexican-style ones. Photograph: Los mercados en Halloween y Día de Muertos (https: / / proyectodf.wordpress. com / $2012 / 11 / 05 / l o s$ mercados-en-halloween-y-diade-muertos /). 
Figure 5. It is possible to see the influence of the US American masks on the Mexican ones. San Agustín Mezquititlán, Hidalgo, Mexico. Photograph by Rosa Isela Aguilar Montes de Oca 2011.

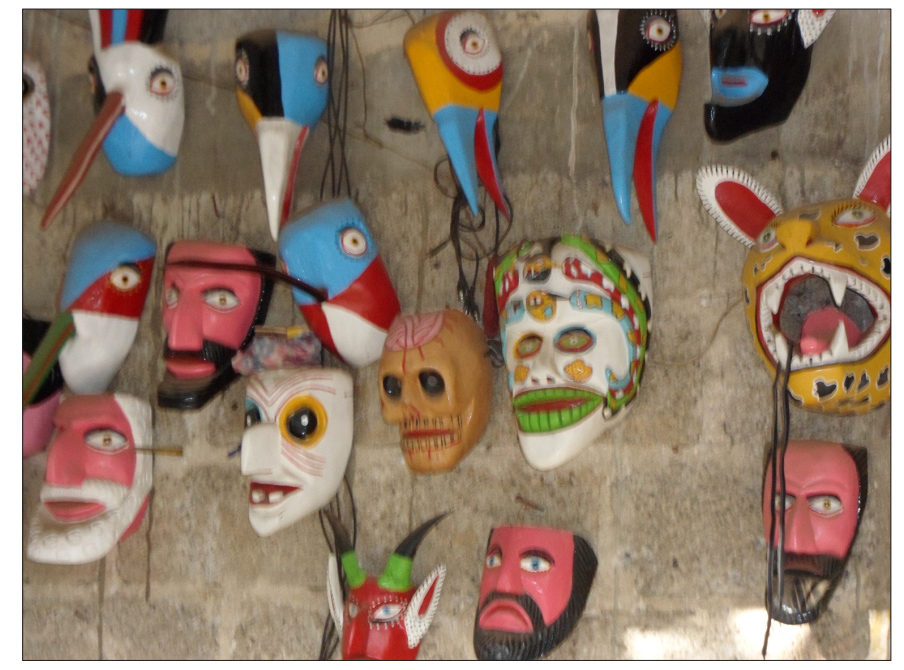

and electrification projects in the region. Halloween masks started to compete with and influence the traditional Day of the Dead in Huejutla and Tehuetlán (Figs. 4, 5). Grim Reapers invaded the scene of the dances, and skulls, Halloween pumpkins, and sweets started to occupy space in the offerings for the dead.

These changes did not persist in the aesthetics of the rituals as the local economy changed dramatically. Instead of producing and consuming local products, the population started to consume imported, expensive ones. Besides, the social relations inside the urban community began to fall apart; yet, they are needed as part of the informal economy within the reciprocity system. Respect for parents, old people, and the dead (one of the most appreciated values in indigenous towns) was missing. This situation was summarized in the $1980 \mathrm{~s}$ by the parish priest of the church of San José, in Tehuetlán, as a result of losing the Xantolo tradition.

\section{THE SEARCH FOR AUTHENTICITY: MISS CEMPOALXÓCHITL BEAUTY PAGEANT AND NEW FOLK COSTUMES}

The parish priest was concerned about the potential threat of losing the meaning of symbols due to the introduction of Halloween items caused by migration and the media. He suggested that the young women of this small city could help to reinvigorate the tradition of the Day of the Dead in La Huasteca and to purify it from the influence of the Halloween. The young ladies were supposed to tell the rest of the population about the importance of the tradition for the 

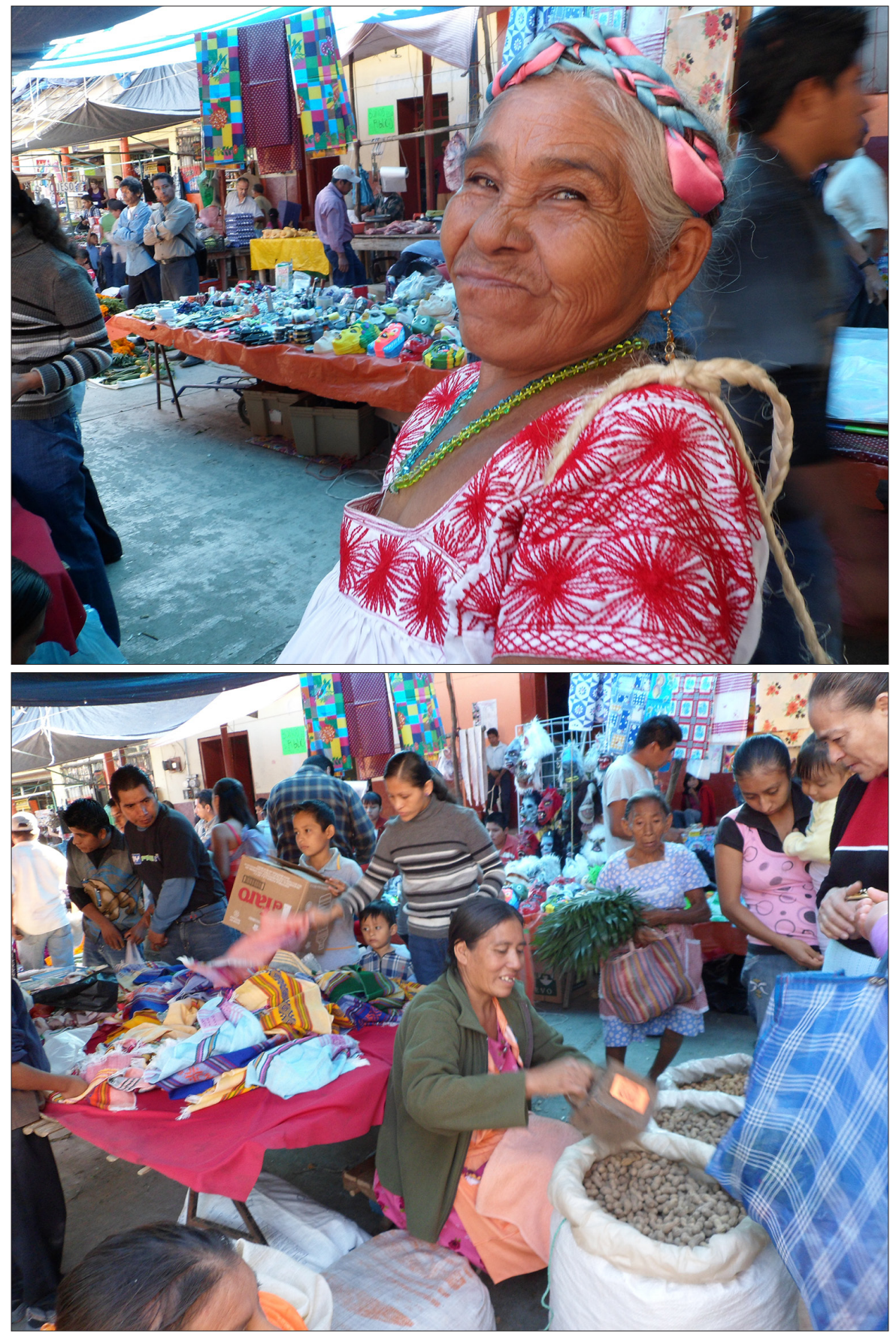

Figures 6, 7. Women at a Saturday market in Tehuetlán; only few of them wear the traditional costume, embroidered by themselves with the typical Huastec flowers. Tehuetlan, Hidalgo, Mexico. Photographs by Rosa Isela Aguilar Montes de Oca 2011. 
community, show the symbols to be used, and explain their meaning. The Miss Cempoalxóchitl contest, started in 1989 to reinforce the Xantolo tradition, is organized by the townspeople in a community-based form called tequio ${ }^{8}$, as part of the Xantolo ritual on the eve of November 1 . The rest of the Xantolo program from October 30 to November 3 has remained the same.

A local schoolteacher decided that the new tradition (the oxymoron is intentional) of the Miss Cempoalxóchitl beauty pageant should use folk costumes as cultural markers to revitalize the tradition and its symbols. This decision followed Miss Universe and Miss World contest models, used since 1962 and 1971, respectively. Traditional folk costumes in Mexico have been of lesser use because the cultural policies, since the 19th century, have insisted on assimilation and integration of the indigenous population into the mainstream culture. These efforts included modern and western clothes. The old folk costumes were taken to the anthropological museum. All around Mexico people using folk costumes were regarded as backward, and this was one of the reasons to abandon this type of clothes. Even if some people still feel comfortable using them, the majority of people living in rural areas have been modernizing their costumes, replacing folk costumes with western clothing style, introduced by modernization processes of the state and as an impact of the diaspora. The Huastec woman's costume, or Nahua costume from La Huasteca, ${ }^{9}$ consists of a blouse and a skirt, hand-embroidered with monochromatic local endemic types of flowers, deer, and birds, and shows the modesty of the Huastec people and their strong connection to nature. Now only old and mainly monolingual women from La Huasteca make and use them to differentiate themselves from the rest of the population (Figures 6,7 ). The old folk costumes were discarded as ritual clothing for the pageant and new ritual clothing was designed for the purpose.

To revive the old tradition, the schoolteacher started to design new representative regional folk costumes, dresses extravagantly adorned with natural and cultural symbols of La Huasteca also used in altars and dances, not only inspired by them, but partially made by using dried corn leaves and flowers, and with headdresses made of natural feathers. Small straw huts, clay pots, guitars, and violins decorate some of the dresses (Fig. 8). But the designs are renewed every year. These new costumes, used only for the Miss Cempoalxóchitl catwalk on November 1, have become ritual folk costumes as they use cultural and natural products of La Huasteca in the traditional festivity on November 1. Hobsbawm (2012) acknowledges that tradition may be invented and can be a recent production. The Miss Cempoalxóchitl pageant is already an established tradition, formalized and ritualized through 26 years of repetition.

The new costumes have slender shapes that emphasize Mexican women's bodies. The dresses worn by the young ladies in Tehuetlán in 2011 were in- 


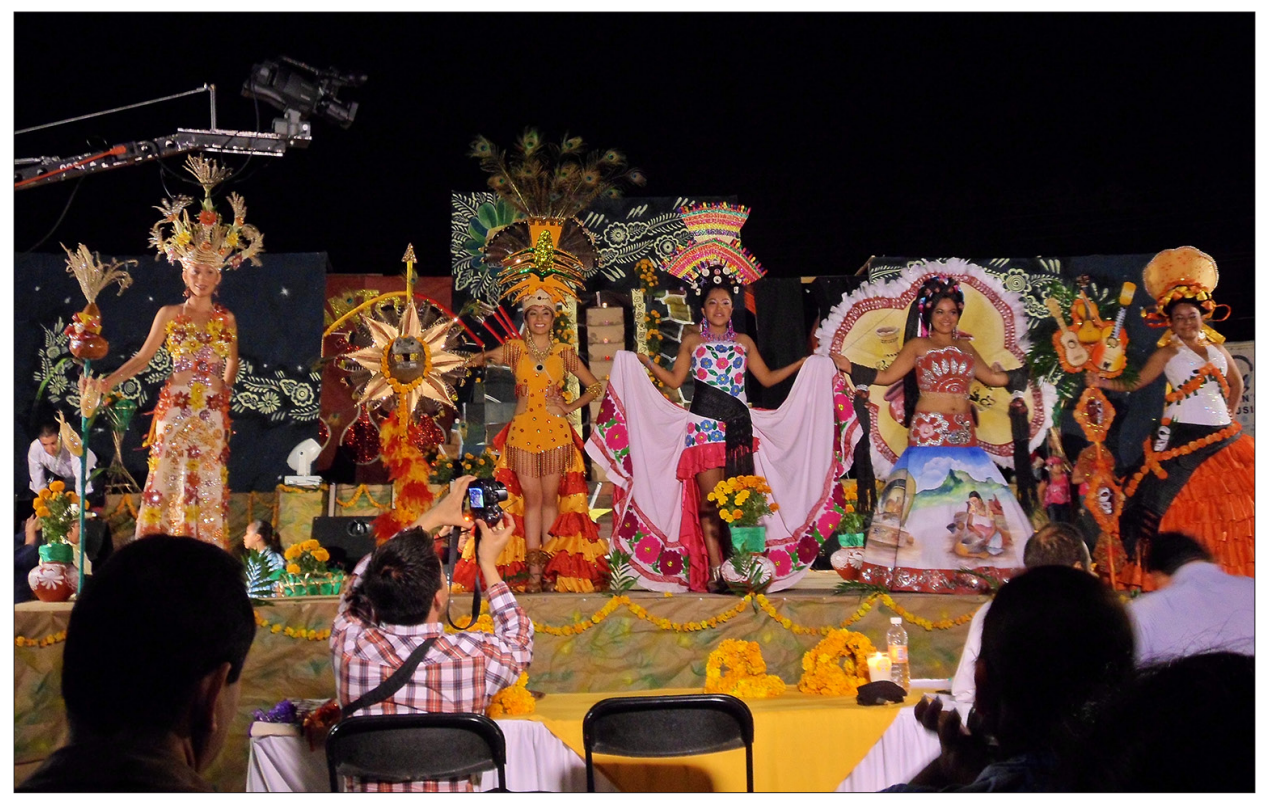

Figure 8. Miss Cempoalxóchitl 2011 Beauty Pageant, planned for months and performed in modern catwalk style. Although it is covered in the media, it remains a very local event. The US American influence is evident in the attempt to foster an authentic, old cultural identity. Tehuetlán, Hidalgo, Mexico. Photograph by Rosa Isela Aguilar Montes de Oca 2011.

spired by the natural and cultural components of the Xantolo ritual: a dress skirt formed as a cempoalxóchitl flower, dresses in the color of cempoalxóchitl or with many flowers, traditional black and white shawls around the waistline and the wrists, colorful ribbons holding hair, clay and golden earrings and colorful golden or flowered necklaces, and a hand-painted skirt depicting the production of clay pots and Huastecos in traditional costumes making corn tortillas, the traditional Mexican food. One of the dresses was hand-embroidered with red, pink, and blue flowers. The most impressive decorations of the dresses were the pre-Hispanic symbols, used by the Toltecs and Aztecs at important ceremonies, such as different kinds of crests (tocado): a corn crest with flowers, a palm crest with clay candle holders and small clay pottery, and a feathered crest (penacho) with golden decorations. Rattles of shell-like seeds were worn round the ankles. ${ }^{10}$ An arrow with small guitars, violins, and masks and flowers attached to it; another with corn leaves, flowers and pottery; and excelling over all, an arrow with an abstract representation of Quetzalcóatl, one of the most important Mesoamerican gods, the feathered serpent, the morning star, the founder of the Toltec Empire (Florescano 2002). Quetzalcóatl dominated the scene with a necklace of cempoalxóchitl and different kinds of feathers. The stage was also decorated with flowers, candles, and clay pots. 


\section{THE ROLES OF THE NEW FOLK COSTUMES: AN OLD CULTURAL IDENTITY}

The Quetzalcóatl myth is strongly related to agriculture, the cultivation of corn, because serpent and bird attributes together indicate the germinating powers of the Earth and creativity of Heaven. Serpents and rain are related in indigenous mythology. Birds are related to the creative powers of Heaven and the feathers of the feathered serpent are from the most beautiful bird in the rainforest, the quetzal, and imply magnificence, splendor, and wealth of Mesoamerican villages. They represent the regeneration of vegetation (Florescano 2002). The Nahua mythology created a legendary Toltecan civilization, guided by their god Quetzalcóatl - the inventors of the calendar, astronomy, writing, agriculture, sciences, and arts, who were the ancestors of the Aztecs and the Chichimecas, those who inherited the great knowledge of Quetzalcóatl (Florescano 1990). Quetzalcóatl appears on the stage of the Miss Cempoalxóchitl contest together with goddesses of the pre-Hispanic era to teach, exactly on the Day of the Dead, the life cycle (which implies death). The god teaches his wisdom, mainly the cyclic calendar and the secrets of agriculture. The Day of the Dead is a harvest festivity, the end of the agricultural cycle. If the wisdom of Quetzalcóatl is adopted, the probability to have a rich harvest increases. It is important for the young generation to learn from these historic lessons, to know how to use the calendar and agricultural knowledge of the region. Then Miss Cempoalxóchitl delineates the relationship with the Huastec ancestors - the Toltecs. The Huastecos draw a non-interrupted history, a connection with the Toltecs up to the settlement of the Huastecos on the territory of La Huasteca. Cyclical time - past, present, and future - in La Huasteca is a real form of existence and not just a Blut und Boden primordialism (not only kinship and territorial primordialism), as Holbraad, Pedersen, and Viveiros de Castro (2014) assert about some ontologies.

This cultural heritage allows the Huastecos to use feather headdresses, arrows, and rattles; to speak Náhuatl; to follow the life cycle to plant, harvest, and consume Huastec products; to protect the endemic fauna and appreciate the beauty of local flowers; to keep alive the modeling of clay pots and figures; to create and perform Huastec lyrics and Huastec music played by violins and small guitars. The renewed Huastec identity defines them as a population living in perfect harmony with nature. The Huastecos perform and hand down their oral tradition and cultural heritage to the next, younger generation, within a limited geographical space, La Huasteca region. And to accomplish these tasks, they use traditional costumes, in this case both old and new, a combination of tradition and modernity. 
Identity construction serves to differentiate oneself from other cultural groups, such as the Huastecos or Nahuas in other states. This differentiation can be of use when receiving economic resources from the state or to distinguish themselves from mestizos. In recent decades, indigenous identity has become important to receive scholarships from the Mexican Educational Institution (SEP) and support for the project of rural development. But it has been of use due to the indigenous empowerment from the state in the agrarian policies pursued in the decade of 1970 (Gabbert 2001).

\section{XANTOLO: CONTINUITIES AND CHANGES AFTER THE ESTABLISHMENT OF MISS CEMPOALXÓCHITL BEAUTY PAGEANT}

When fostering the Xantolo ritual, the Miss Cempoalxóchitl contest reinvigorates local economy and the social networks in Tehuetlán. Geographically well located, it connects the cities of Huazalingo, Huejutla, and Tlanchinol, and is an important way to Veracruz and San Luis Potosí (Vargas del Ángel 2010). The community works for the ritual for several months ahead and some of the outcomes represent the reactivation of local economy, such as the production of symbolic items needed to decorate ofrendas and altars and to perform dances. The Miss Cempoalxóchitl contest starts on June 24, the day of Saint John, which marks the beginning of the sowing season, extends to the harvest season in October, and ends on November 3, when the last dead leave. Small and big towns of the entire La Huasteca region profit from this celebration. Some communities are specialized in the manufacturing of pottery; others make masks, candles, guitars, violins, fireworks, and costumes. Some people are hired as musicians, many as dancers, some offer their workforce to build arches for the altars, and some others to light the fireworks. From other cities come vendors who bring (US American) hamburgers, Spanish churros (snack of fried sweet dough), and Mexican fried bananas. The locals sell their corn specialties: enchiladas, tostadas, and morelianas. ${ }^{11}$ Funfairs come to town because the Xantolo is also a fair for children. Not only the usual products are needed for the Xantolo; new products also have to be manufactured for the Miss Cempoalxóchitl contest: the stage, the dresses, the headdresses. Camera men, stage managers, and photographers are hired for the contest, even if it remains a local event. There are no tourists, but the families want to record the moments in videos and photographs as memories. After the pageant, a community dance event and a semi-formal dinner party are announced. Informal vendors are also there to offer local specialties. 
The Xantolo serves to reunite families and to reinforce kinship ties; it is much more important than Christmas in La Huasteca. The organization of the contest that starts months before is also an opportunity to reinforce networks, to work together with the community in this cultural project. Community members meet on three previous Saturday market days, in the center of the town, where they go to buy special products for the festivity. On the last Saturday they go to bakeries to get the appreciated sweet bread from Tehuetlán, which is served to the members of the family who visit. The family members in town work together. Children meet several times when they go to mills to grind corn to make dough for making tortillas and tamales. And the family members together prepare tamales and handmade chocolate bars.

The Miss Cempoalxóchitl pageant has introduced a new form of networking within the town. Many girls visit homes months before to introduce themselves, to tell about their connections with their culture and their hometown. They are looking for sponsors and distribute gifts to gain people's approval for the pageant. Only five girls are selected for the final round. In the afternoon, the community gathers in the center of the town to encourage and cheer the young participants. The spectators are all excited and enthusiastically talk about their feelings, the girls, and the dresses. On the catwalk the young women in magnificent dresses talk about their experiences with people from La Huasteca region, the tradition of Xantolo, and its symbols. One of them is declared Señorita Cempoalxóchitl, the other four acting as her princesses. After the contest, the happy community enjoys the local food and music.

The community has no economic resources to organize the Xantolo project with music, dances, and the Miss Cempoalxóchitl contest independently. The investment is an agreement between the community, the bigger shops (grandes negocios) in town, and the municipality. In 2011 the Xantolo investment amounted to about 150,000 pesos (8900 US dollars, currency exchange rate of 13.09.2015). It means an annual investment of about 2 US dollars per person. The municipality's participation was 25,000 pesos (1485 US dollars). The rest was mainly the contribution of the big shops in town. The shops contribute and expect as compensation the continuation of the political party voting machine. The negative outcome is the reinforcement of the cacicazgo ${ }^{12}$ system in the region. The population accepts this asymmetrical agreement with shops and institutions (which normally are the same families) in order to perform the Xantolo ritual and to reinvigorate their local mixed economy. The Miss Cempoalxóchitl contest increases the dependency of the population on big shops, yet they use this opportunity to allure the members of the family in the diaspora by the attractive American, urban, modern discourse, to foster the cultural identity in the diaspora, and to show them that it is possible to be part 
of Huasteco diaspora, and urban and rural, modern and traditional Huastecos at the same time. The remembrance of dead family members touches the deeper sense of being, bringing the members of the diaspora home once a year.

The Miss Cempoalxóchitl beauty pageant serves to modernize the representation of gender and gender roles in town. The new ritual folk costumes promote the Huastec identity, but they are not related to monolingual women. Miss Cempoalxóchitl embodies the US American ideal of womanhood: modern, stylized, beautiful, tall, thin, and white-skinned. Its dresses are adjusted to the bodies of more modern, western young women. But at the same time old attributes of a good woman are reinforced: her role as the custodian of the culture, femininity, gracefulness, and orientation to family and housewifeliness. Both traditional and modern gender representations can be found in town. Most of the women decorate the altars and cook for the festivity, but some of them present themselves as Toltecan goddesses on the catwalk.

\section{CONCLUSIONS}

This example shows that the revitalization of an old tradition can be done through the construction of a new one. The Miss Cempoalxóchitl contest is a new tradition with new costumes to revitalize an old tradition, Xantolo, and an old identity, Huasteco. Since 1989, Xantolo rituals have had three components in Tehuetlán: altars, dances, and the Miss Cempoalxóchitl contest. Together, they foster the cultural heritage. The new costumes open up possibilities for shaping an original identity, directly related to the Toltecs, in which time and space coincide and permit a real connection with La Huasteca territory. Hence, all this reinforces the Huasteco identity. The cultural authenticity of this annual reunion with the dead works against the effects of US American influence and revitalizes the sense of community and regional economy.

The Xantolo ritual instigates the creativity of the community; every year new folk dresses are designed with natural and cultural symbols from La Huasteca. It helps to renew kinship and community ties through a well-established reciprocity system, and to bring families together. It brings jobs to smaller and bigger communities during half a year period, when different towns in the region are busy preparing products for the ritual.

The paradox in this story is that the cultural influence from abroad, which was supposed to be undesirable for the local tradition of Xantolo, has actually fostered the tradition. This example shows that culture is a continuous transcultural process. Even if on the outside the ritual seems to be unchangeable, except for the Miss Cempoalxóchitl pageant, changes are constantly taking 
place. Based on their experiences, the inhabitants of Tehuetlán have introduced some cultural characteristics of the United States into their town, and so has the media. The Mexican masks and costumes are charged with Halloween and everyday costumes from abroad, such as cowboys and Comanches, and even the representation of death. Women's daily dresses have also changed. The change of women's folk costumes for the representation of Miss Cempoalxóchitl, as well as modern gender representations and gender roles, is the result of transcultural processes, mainly that of Miss Universe and Miss World contests. This process of modernization through the Miss Cempoalxóchitl contest is by no means accepted by the entire community. For some - mainly those living outside Tehuetlán - this is not the right way to reinforce the traditions which should be purged from alien influence.

\section{NOTES}

1 This paper is still in research phase and its findings are not yet conclusive.

2 The Treaty of Guadalupe Hidalgo in 1848 ended the U.S. war with Mexico, when Mexico ceded a large part of its territory to the United States. Mexico needed then a national identity to prevent further invasions.

3 Marchi (2005) finds that the Mexican diaspora in the United States uses the Day of the Dead for political purposes in some other ways. The ritual is a form of communication for populations with restricted access to conventional media production. It is an opportunity for identity construction, education, or protest. It creates a sense of community and belonging, and increases opportunities for political communication to transmit information, to exchange ideas, and even to inspire community activism.

4 Those who died in water or were killed by lightning went to the paradise of Tláloc (the ruler of the heavens). They were not burned but buried and honored in the Tepeilhuitl festivity. The special dead and the god of fire, Xiutecuhtli, were honored during the month of Izcalli, the last month in the Aztec calendar. In this ritual five tamales were offered in five different graves. Afterwards, the tamales had to be eaten.

5 Aztecs prepare tamalli (the Náhuatl word for tamales): steaming corn meal wrapped in corn leaves. Tamales are stuffed with different stews around Latin America (Pradeau 1974).

6 Náhuatl is the language of the Aztecs, the direct descendant of Toltecs. In La Huasteca the local variation is called Náhuatl de la Huasteca (Valle Esquivel 2003).

7 This conflict between Comanches and cowboys originates from the United States, but the relationship with the Xantolo ritual in Tehuetlán has not been analyzed.

8 Tequio (kwatekwitl in Náhuatl, also called faena, faina, or fagina, depending on the ethnical group) is work without economic compensation under the supervision of local authorities in order to improve the community (De la Fuente 1944). 
9 Nahua de la Huasteca is another name to refer to Huastecos, who speak the Huastec version of the Náhuatl language (Valle Esquivel 2003).

${ }^{10}$ Rattles from chalchahuite or ayoyote shells (conchas o cascabeles) produce a kind of pre-Columbian music that complements the steps of the Aztec concheros dances. But according to Vento (1994) these dances started after the Spanish conquest, when natives were allowed to perform their dances in the courtyards of churches to honor saints and virgins.

${ }^{11}$ Corn specialties in a variation of forms that usually combine corn dough, beans paste, chili sauce, cheese, and vegetables.

${ }^{12}$ Cacicazgo is defined as a Mexican informal political leadership of a cacique, parallel to the state, which holds an arbitrary control of a group of individuals. Historically, some indigenous peoples in Mexico were organized in cacicazgos due to the agrarian policies of the 19th century (Friedrich 1965). Caciques originally held a position within the Aztec aristocracy, along with local chiefs, military officers, tribute collectors, priests, judicial authorities, and miscellaneous state officials. The local community chief was called Tlatohuani (plural Tlatoque). These leaders were recognized by the Spanish politicians, during the colonial era, as caciques (Gibson 1960). During the revolution, some servicemen regarded themselves as caciques, and more recently caciques have been affiliated to political parties and hold formal or informal control of small towns (Falcón 1983).

\section{REFERENCES}

Brandes, Stanley 1998. The Day of the Dead, Halloween, and the Quest for Mexican National Identity. Journal of American Folklore, Vol. 111, No. 442, pp. 359-380. http://dx.doi.org/10.2307/541045.

Brandes, Stanley 2003. Is There a Mexican View of Death? Ethos, Vol. 31, No. 1, pp. $127-$ 144. http://dx.doi.org/10.1525/eth.2003.31.1.127.

Dufétel, Dominique 2011. Los antepasados ocultos. [The Hidden Ancestors.] Artes de México, No. 62, pp. 10-15. Available at http://www.jstor.org/stable/24314375, last accessed on September 9, 2016.

Dürr, Eveline 2009. Kulturbegegnung und Identitätsbildung. Ethnologische Perspektiven auf transkulturelle Prozesse. In: Alois Moosmüller (ed.) Konzepte kultureller Differenz. Münster: Waxmann, pp. 179-194.

Falcón, Romana 1983. El sistema frente al cacicazgo: El caso de Cedillo. [The Political System in front of Cacicazgo System: The Case of Cedillo.] Diálogos: Artes, Letras, Ciencias humanas, Vol. 19, No. 5 (113), pp. 77-86. Available at http:// www.jstor.org/stable/27934831?seq=1\#page_scan_tab_contents, last accessed on September 9, 2016.

Florescano, Enrique 1990. Mito e historia en la memoria nahua. [Myth and History in the Nahua Social Memory.] Historia mexicana, Vol. 39, No. 3, pp. 607-661. Available at http://codex.colmex.mx:8991/exlibris/aleph/a18_1/apache_media/ BC3FFRVKK7LYEN4TTUGVDKP8PU8KXS.pdf, last accessed on September 9, 2016. 
Florescano, Enrique 2002. El simbolismo de Quetzalcóatl. [The Symbolism of Quetzalcoatl.] Artes de México, No. 32, pp. 18-27. Available at http://www.jstor.org/ stable/24326585, last accessed on September 9, 2016.

Friedrich, Paul 1965. A Mexican Cacicazgo. Ethnology, Vol. 4, No. 2, pp. 190-209. http:// dx.doi.org/10.2307/3772729.

Fuente, Julio de la 1944. Cooperación indígena y cooperativismo moderno. [Indigenous Cooperation System and Modern Cooperativism.] El Trimestre Económico, Vol. 10, No. 40 (4), pp. 749-765. Available at http://aleph.academica.mx/jspui/ bitstream/56789/7772/1/DOCT2064759_ARTICULO_4.PDF, last accessed on September 8, 2016.

Gabbert, Wolfgang 2001. Social Categories, Ethnicity and the State in Yucatán, Mexico. Journal of Latin American Studies, Vol. 33, No. 3, pp. 459-484. http://dx.doi. org/10.1017/S0022216X01005983.

Gibson, Charles 1960. The Aztec Aristocracy in Colonial Mexico. Comparative Studies in Society and History, Vol. 2, No. 2, pp. 169-196. http://dx.doi.org/10.1017/ S0010417500000657.

Haley, Shawn D. \& Fukuda, Curt 2004. Day of the Dead: When Two Worlds Meet in Oaxaca. New York: Berghahn Books.

Hobsbawm, Eric 2012. Introduction: Inventing Traditions. In: Eric Hobsbawm \& Terence Ranger (eds.) The Invention of Tradition. Cambridge: Cambridge University Press, pp. 1-14. Available at: http://faculty.washington.edu/ellingsn/Hobsbawm Inventing_Traditiions.pdf, last accessed on September 9, 2016.

Holbraad, Martin \& Pedersen, Morten Axel \& Viveiros de Castro, Eduardo 2014. The Politics of Ontology: Anthropological Positions. Cultural Anthropology Online. Available at http://culanth.org/fieldsights/462-the-politics-of-ontologyanthropological-positions, last accessed on September 8, 2016.

Kummels, Ingrid 2007. Die Liebe in den Zeiten der Diaspora: Globale Märkte und lokale Bedeutungen von Prostitution, jineterismo, Ehe und Weiblichkeit in Kuba. In: Stephanie Schütze \& Martha Zapata Galindo (eds.) Transkulturalität und Geschlechterverhältnisse: Neue Perspektiven auf kulturelle Dynamiken in den Amerikas. Berlin: Edition Tranvía \& Walter Frey, pp. 172-195.

Lechuga, Ruth D. 2011. Rituales del día de muertos. [The Day of the Dead Rituals.] Artes de México, No. 62, pp. 16-25. Available at http://www.jstor.org/stable/24314376, last accessed on September 9, 2016.

Linton, Ralph 1951. Halloween. Scientific American, Vol. 185, No. 4, pp. 62-66. doi:10.1038/scientificamerican1051-62.

Marchi, Regina M. 2005. Altar Images: US Day of the Dead as Political Communication. Diss. (PhD Thesis). UC San Diego Electronic Theses and Dissertations. Available at http://escholarship.org/uc/item/8574v2sk, last accessed on September 9, 2016.

Meyer, Birgit \& Geschiere, Peter 1999. Globalization and Identity: Dialectics of Flow and Closure. Introduction. In: Birgit Meyer \& Peter Geschiere (eds.) Globalization and Identity: Dialectics of Flow and Closure. Oxford: Blackwell Publishing, pp. 1-16.

Orellana, Margarita de 2011a. Nuevas preguntas al día de muertos. [New Questions about the Day of the Dead.] Artes de México, No. 62, pp. 6-9. Available at http:// www.jstor.org/stable/24314374, last accessed on September 8, 2016. 
Orellana, Margarita de 2011b. La muerte sonriente. [Death's Grin.] Artes de México, No. 67, pp. 6-7. Available at http://www.jstor.org/stable/24315566, last accessed on September 8, 2016.

Ortiz, Fernando 1995 [1947]. Cuban Counterpoint: Tobacco and Sugar. Durham and London: Duke University Press.

Paz, Octavio 1961. The Labyrinth of Solitude. Trans. by Lysander Kemp. New York: Grove Press.

Pradeau, Alberto Francisco 1974. Pozole, Atole and Tamales: Corn and Its Uses in the Sonora-Arizona Region. The Journal of Arizona History, Vol. 15, No. 1, pp. 1-7. Available at: http://www.jstor.org/stable/41695162?seq=1\#page_scan_ tab_contents, last accessed on September 9, 2016.

Schlehe, Judith 2005. Transkulturalität in der Ethnologie: neue Forschungsbeziehungen. Heidelberg: Vortrag an der Universität. Available at: http://www.uni-heidelberg. $\mathrm{de} / \mathrm{md} /$ zaw/akh/akh_texte/04schlehe240605.pdf, last accessed on September 9, 2016.

Schryer, Frans J. 1990. Ethnicity and Class Conflict in Rural Mexico. Princeton: Princeton University Press.

Schütze, Stephanie \& Zapata Galindo, Martha 2007. Transkulturalität und Geschlechterverhältnisse. Neue Perspektiven auf kulturelle Dynamiken in den Amerikas. In: Stephanie Schütze \& Martha Zapata Galindo (eds.) Transkulturalität und Geschlechterverhältnisse: Neue Perspektiven auf kulturelle Dynamiken in den Amerikas. Berlin: Edition Tranvía \& Walter Frey, pp. 7-19.

Valle Esquivel, Julieta 2003. Nahuas de la Huasteca. [Nahuas from la Huasteca.] México: CDI. Available at: http://www.cdi.gob.mx/dmdocuments/nahuas_huasteca.pdf, last accessed on September 8, 2016.

Vargas del Ángel, Irla Élida 2010. Celebración del Xantolo en las comunidades indígenas nahuas. [The Celebration of Xantolo in Indigenous Nahua Communities.] Olinka. Hidalgo State Ministry of Education, pp. 9-11.

Vento, Arnoldo Carlos 1994. Aztec Conchero Dance Tradition: Historic, Religious and Cultural Significance. Wicazo Sa Review, Vol. 10, No. 1, pp. 59-64. Available at: http://www.jstor.org/stable/1409310?seq=1\#page_scan_tab_contents, last accessed on September 9, 2016. 